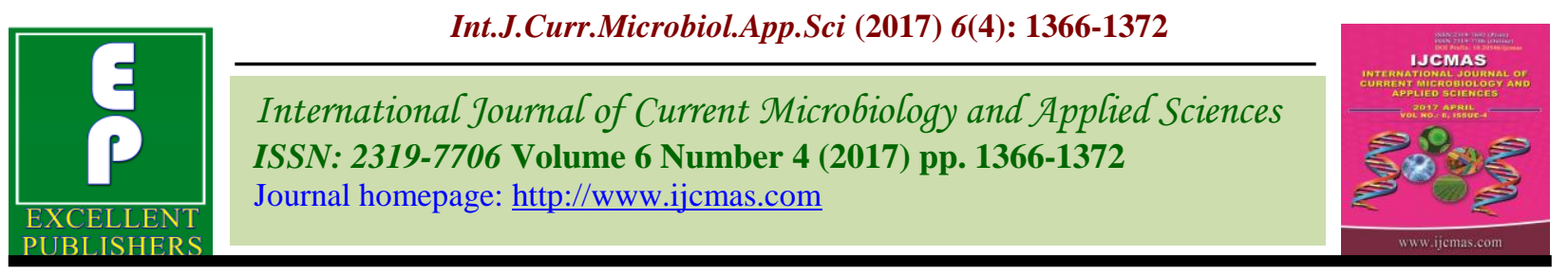

Original Research Article

https://doi.org/10.20546/ijcmas.2017.604.167

\title{
Influence of Pre Harvest Application of Calcium on Shelf Life and Fruit Quality of Mango (Mangifera indica L.) Cultivars
}

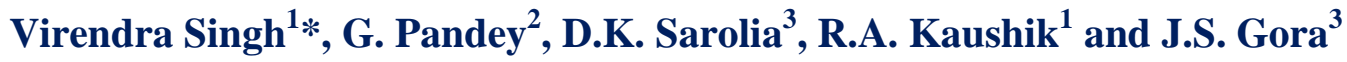 \\ ${ }^{1}$ AICRP on fruits, Department of Horticulture, RCA, Udaipur, India \\ ${ }^{2} \mathrm{CISH}$, Lucknow, India \\ ${ }^{3} \mathrm{CIAH}$, Bikaner, India \\ *Corresponding author
}

\section{A B S T R A C T}

Keywords

Mango, Dashehari, Amrapali, Shelf life, Calcium compounds

Article Info

Accepted:

12 March 2017

Available Online:

10 April 2017
The effect of pre harvest spraying of calcium chloride $\left(\mathrm{CaCl}_{2}\right)$ and calcium nitrate $(\mathrm{Ca}$ $\mathrm{NO}_{3}$ )@ 0.5 and $1 \%$ on shelf life and quality attributes of mango cvs Dashehari and Amrapali was investigated. Pre harvest spray was carried out on fully grown mango trees prior to one month of harvesting following second subsequent spray, 15 days after of first one. Full ripe fruits of both the cultivars were packed in brown papers bags after washing and surface air drying and stored under ambient condition $\left(36 \pm 2{ }^{\circ} \mathrm{C}\right.$ at $\left.75 \pm 3 \% \mathrm{RH}\right)$. Cumulative physiological loss in weight, spoilage duration, shelf life and the chemical changes viz. total soluble solids, acidity, total sugars and phenols associated with ripening were monitored. Double sprays of $\mathrm{Ca} \mathrm{NO}_{3}$ ) $1 \%$, showed an extended shelf-life of 7 and 7.4 days in Dashehari and Amrapalli, respectively in comparison to 5 days in control with maximum organoleptic score. Results indicated that different pre harvest spraying of calcium compounds were significantly enhanced the fruit quality and shelf life of both the mango cultivars compared to control.

\section{Introduction}

Mango (Mangifera indica Linn.), the most important commercial fruit, which occupies an area of 2.52 million ha with an annual production of 18.43 million tonnes in India (Indian Horticulture database, 2015). Dashehari and Amrapali are the most popular cultivars of mango in this zone due to unique taste and consumer likings. Like most of the other fruits, Mango is also seasonal and perishable in nature. Mango is a climacteric fruit generally harvested green, which ripens during the marketing process (transport, storage etc.) with an irregular storage period between harvest and consumption. Mango is a fleshy fruit containing more than 80 per cent water are more prone to spoilage. The glut during peak harvesting season and rapid ripening process i.e. sudden rise in respiration rate and ethylene production are the conditions subjected to spoilage. To avoid glut during peak season of harvesting and provide good returns to orchardist, it becomes essential to store the mango fruits for selling in phased manner. Hence, it is essential to develop some pre and post harvest mechanism to improve the storage life in order to regulate the supply of quality mango fruits for longer period on domestic and 
distant market. Fruits stored in modified atmosphere often show undesirable characteristics, i.e. poor colour, poor eating quality and presence of undesirable flavours. So, to solve the problem of short shelf-life of mango fruits, different chemicals are used to delay the ripening (Suhardi, 1992). Several pre and post harvest methods are known to extend the storage life of mango fruits by minimizing weight loss, reduction in rate of respiration, transpiration and rotting percentage by use of calcium compounds as pre harvest spray and post harvest dip treatments (Singh et al., 1998; Eimer et al., 2006 and Lanaouskas and Kvikliene, 2006). Calcium, as a constituent of the cell wall, plays an important role in forming crossbridges, which influence cell wall strength and regarded as the last barrier before cell separation (Fry, 2004). Calcium compounds (chloride and nitrate) treatments have been found to have some beneficial effect like prevention of decline in ascorbic acid (Kwon et al., 1999), phenol content (Sharma et al., 1996) and reduce softness of pulp adhering stone etc for improving the quality and shelf life of mango fruits.

\section{Materials and Methods}

Pre-harvest spraying of calcium chloride and calcium nitrate on mango fruits of cv. Dashehari and Amrapali was carried out at Agricultural Research Station, Banswara, Maharana Pratap University of Agriculture and Technology, Udaipur, Rajasthan, during 2010-11 to 2013-14 on 15 years old uniform size fully grown bearing trees. Calcium chloride $\left(\mathrm{CaCl}_{2}\right)$ and calcium nitrate $\left(\mathrm{CaNO}_{3}\right)$ @ 0.5 and 1 per cent as single and double spray along with control (spray of plain water) were applied at one month prior to harvesting and subsequent second spray 15 days after first one on both the cultivars (Dashehari and Amrapali). Physiologically mature uniform size fruits were harvested and subjected to remove field heat by washing followed by surface air drying. Uniformity in experiment was maintained based on selection of fruits by specific gravity (floaters) and fruit weight in Amrapali (165-175 g) and Dashehari (175-185 g) in Complete Randomized Design with four replications (Panse and Sukhatme, 1985). Surface air dried fruits of both the cultivars along with control were stored in brown paper bags at ambient temperature $\left(36 \pm 2^{0} \mathrm{C}\right.$ at $75 \pm 2 \%$ $\mathrm{RH})$ for ripening and record the observation on two stages of ripening at $7^{\text {th }}$ day of storage and full ripening stage. Observation on different physical (fruit firmness, weight loss, days to ripening, shelf life and organoleptic score) and biochemical (TSS, acidity, total sugar and phenol content) attributes were recorded on both the stages in both the cultivars (Tables 1 and 2). Physical parameters of mango fruits were determined as per standard methodology. Specific gravity was calculated by the formula Specific gravity $=$ Mass $/$ volume, The firmness of fruit $(\mathrm{kg} \mathrm{cm})^{-2}$ was determined by Texture Analyzer of "Stable Micro System" limited using cylinder probe with $5 \mathrm{~kg}$ load cell and heavy duty platform. CPLW (Cumulative physiological loss in weight) was calculated by using following formula:

\section{$\operatorname{CPLW}(\%)=$}

Initial weight $(\mathrm{g})$ - final weight $(\mathrm{g})$

Initial weight (g)

Ripening and spoilage days were calculated after harvesting of physiologically mature fruits and shelf life recorded after ripening of fruits. For chemical analysis, a representative sample was taken from each unit (5 fruits) by cutting a slice of mesocarp and homogenizing it. Total soluble solids of juice were measured with the help of hand refractometer. The titrable acidity of the fruit juice was 
determined by the method given by Rangana (1979) and expressed as citric acid in grams per $100 \mathrm{ml}$ of juice. Total sugar and phenol content was determined by using anthrone reagents (Dubois et al., 1951) and Folinciocalteau reagent (AOAC, 1995), respectively.

\section{Results and Discussion}

\section{Dashehari}

Data revealed that the application of calcium compounds significantly influenced physical quality of mango fruits along with organoleptic score. Untreated Dashehari mango fruits start ripening ( $5^{\text {th }}$ day) and reach to deterioration stage ( $9^{\text {th }}$ day) compared to 1 per cent calcium nitrate double spayed fruits by delayed ripening $\left(7^{\text {th }}\right.$ day) and subsequently deterioration stage (13.0 days). Maximum fruit firmness $\left(3.47 \mathrm{kgcm}^{-2}\right)$, shelf life (6.0 days) and organoleptic score (8.9) was registered under $T_{8}$ followed by $T_{4}$ treatment compared to minimum in $T_{1}$ (control). Minimum loss in weight was recorded with double sprayed $1 \% \quad \mathrm{CaNO}_{3}$ $(3.50 \%)$ followed by $\mathrm{CaCl}_{2}(3.43 \%)$ while maximum in control $(9.40 \%)$ at control ripening stage (Table 1$)$.

Total soluble solids, acidity, total sugar and phenol contents were also significantly influenced by application of calcium compounds over control. In control ripe stage, bio-chemical quality attributes like TSS, total sugars were higher and acidity and phenol were lower in control (unsprayed) fruits indicated that fruits of this treatment can not be stored further, however, fruits from rest of the treatments can be stored further as it recorded lowest total soluble solids $(16.8 \%)$ and sugar $(12.07 \%)$ along with higher acidity $(0.37 \%)$ and phenol (1.05\%) content in double sprayed with $1 \% \mathrm{CaNO}_{3}$ followed by $1 \% \mathrm{CaCl}_{2}$. At full ripening stage maximum
TSS $(21.2 \%)$ and total sugars $(15.26 \%)$ were also recorded in $\mathrm{CaNO}_{3} @ 1.0 \%$ treatment $\left(\mathrm{T}_{8}\right)$.

\section{Amrapali}

Calcium compounds significantly influenced physico-chemical attributes. The trend of comparative efficacy among the treatments with more or less similar to Dashehari cultivar i.e., most potent chemical was $\mathrm{CaNO}_{3}$. Unsprayed (control) fruits start ripening on $5^{\text {th }}$ day of storage to $7.4^{\text {th }}$ day in treatment $T_{8}$ and subsequently start deterioration after $10^{\text {th }}$ day. The total difference in shelf life storage between them under ambient temperature $\left(36 \pm 2{ }^{\circ} \mathrm{C}\right.$ at $\left.79 \% \mathrm{RH}\right)$ is minimum 3.25 days in control and maximum 5.50 days in 1 per cent double spray $\mathrm{CaNO}_{3}$ (Table 2). Among the cultivars Dashehari showed higher shelf life, fruit firmness and lower loss in weight over Amrapali, but in chemical quality attributes including organoleptic score cv. Amrapali was better over Dashehari.

Calcium treated fruits were better in respect to most of the attributes over control which might be due to $\mathrm{Ca}^{2+}$ ion alters intracellular and intercellular biological activity, resulting in retard ripening exemplified by lower rates of pigment change (Singh et al., 1993), softening (Stow, 1993 and Tandon and Kalra, 1997) $\mathrm{CO}_{2}$ and ethylene $\left(\mathrm{C}_{2} \mathrm{H}_{4}\right)$ production (Sams and Conway, 1984), increase in sugar and a reduction of total acid content (Tirmazi and Wills, 1981). Calcium, as a constituent of the cell wall, plays an important role in forming cross-bridges, which influence cell wall strength and regarded as the last barrier before cell separation (Fry, 2004). Other possible reason might be that some calcium salts especially calcium chloride and calcium nitrate have been reported in literature to delay the ripening and senescence in fruits by lowering the respiration rate [Singh et al. 1993]. 


\section{Int.J.Curr.Microbiol.App.Sci (2017) 6(4): 1366-1372}

Table.1 Nutritive value of ripe mango per $100 \mathrm{~g}$

\begin{tabular}{|c|c|c|c|c|c|c|c|c|c|c|c|c|}
\hline \multirow{3}{*}{ Treatments } & \multicolumn{12}{|c|}{ Cultivars } \\
\hline & \multicolumn{6}{|c|}{ Dashehari } & \multicolumn{6}{|c|}{ Amrapali } \\
\hline & $\begin{array}{l}\text { Firmness } \\
\left(\mathrm{kg} / \mathrm{cm}^{2}\right)\end{array}$ & $\begin{array}{c}\text { CPLW } \\
(\%)\end{array}$ & $\begin{array}{l}\text { Ripening } \\
\text { (days) }\end{array}$ & $\begin{array}{l}\text { Shelf life } \\
\text { (days) }\end{array}$ & $\begin{array}{c}\text { Spoilage } \\
\text { (days) }\end{array}$ & $\begin{array}{c}\text { Organole- } \\
\text { ptic Score } \\
(10)\end{array}$ & $\begin{array}{l}\text { Firmness } \\
\left(\mathrm{kg} / \mathrm{cm}^{2}\right)\end{array}$ & $\begin{array}{c}\text { CPLW } \\
(\%)\end{array}$ & $\begin{array}{l}\text { Ripening } \\
\text { (days) }\end{array}$ & $\begin{array}{c}\text { Shelf } \\
\text { life } \\
\text { (days) }\end{array}$ & $\begin{array}{c}\text { Spoilage } \\
\text { (days) }\end{array}$ & $\begin{array}{c}\text { Organole- } \\
\text { ptic score } \\
(10)\end{array}$ \\
\hline $\mathrm{T}_{1-} \mathrm{Ca} \mathrm{Cl}_{2} 0.5 \%$ (Single spray) & 2.43 & 4.90 & 5.3 & 4.00 & 9.50 & 7.0 & 2.29 & 9.10 & 5.7 & 3.75 & 10.00 & 7.00 \\
\hline $\mathrm{T}_{2-} \mathrm{Ca} \mathrm{Cl}_{2} 0.5 \%$ (Double spray) & 2.87 & 4.20 & 6.2 & 4.50 & 11.00 & 7.50 & 3.19 & 8.03 & 6.5 & 4.00 & 11.60 & 8.00 \\
\hline $\mathrm{T}_{3-} \mathrm{Ca} \mathrm{Cl}_{2} 1 \%$ (Single spray) & 2.97 & 4.10 & 6.3 & 4.50 & 11.25 & 7.75 & 3.18 & 8.43 & 6.5 & 4.50 & 11.50 & 7.75 \\
\hline $\mathrm{T}_{4-} \mathrm{Ca} \mathrm{Cl}_{2} 1 \%$ (Double spray & 3.37 & 3.43 & 6.3 & 5.50 & 12.50 & 9.0 & 3.62 & 5.27 & 7.0 & 5.25 & 12.80 & 9.0 \\
\hline $\mathrm{T}_{5-} \mathrm{Ca} \mathrm{NO}_{3} 0.5 \%$ (Single spray & 2.90 & 4.77 & 6.0 & 4.75 & 11.00 & 7.0 & 3.00 & 8.90 & 6.5 & 3.75 & 11.50 & 7.50 \\
\hline $\mathrm{T}_{6-} \mathrm{Ca} \mathrm{NO} \mathrm{NO}_{3} 0.5 \%$ (Double spray & 3.20 & 4.43 & 6.3 & 5.50 & 11.50 & 7.50 & 3.00 & 6.87 & 7.0 & 4.00 & 13.00 & 8.50 \\
\hline $\mathrm{T}_{7-} \mathrm{Ca} \mathrm{NO}_{3} 1 \%$ (Single spray & 3.30 & 4.20 & 6.5 & 5.75 & 12.00 & 8.0 & 3.20 & 8.77 & 7.2 & 4.75 & 13.25 & 8.50 \\
\hline $\mathrm{T}_{8-} \mathrm{Ca} \mathrm{NO}_{3} 1 \%$ (Double spray & 3.47 & 3.50 & 7.0 & 6.00 & 13.00 & 8.9 & 3.69 & 5.03 & 7.4 & 5.50 & 13.50 & 9.00 \\
\hline $\mathrm{T}_{9-}$ Control & 1.33 & 9.40 & 5.0 & 4.00 & 9.00 & 5.50 & 1.40 & 11.43 & 5.0 & 3.25 & 10.00 & 6.50 \\
\hline $\mathrm{SEm} \pm$ & 0.070 & 0.12 & 0.15 & 0.18 & 0.30 & 0.29 & $\mathbf{0 . 0 3}$ & 0.21 & 0.12 & 0.18 & 0.29 & 0.29 \\
\hline $\mathrm{CD}$ at $5 \%$ & 0.21 & 0.35 & 0.46 & 0.56 & 0.91 & 0.87 & 0.08 & 0.62 & 0.37 & 0.56 & 0.87 & 0.87 \\
\hline
\end{tabular}




\section{Int.J.Curr.Microbiol.App.Sci (2017) 6(4): 1366-1372}

Table.2 Effect of pre harvest spray of calcium compounds on bio-chemical attributes of mango cultivars

\begin{tabular}{|c|c|c|c|c|c|c|c|c|c|c|c|c|c|c|c|c|}
\hline \multirow[t]{4}{*}{ Treatments } & \multicolumn{16}{|c|}{ Cultivars } \\
\hline & \multicolumn{8}{|c|}{ Dashehari } & \multicolumn{8}{|c|}{ Amrapali } \\
\hline & \multicolumn{2}{|c|}{ TSS (\%) } & \multicolumn{2}{|c|}{ Acidity (\%) } & \multicolumn{2}{|c|}{ Total Sugar $(\%)$} & \multicolumn{2}{|c|}{ Phenols (\%) } & \multicolumn{2}{|c|}{ TSS (\%) } & \multicolumn{2}{|c|}{ Acidity (\%) } & \multicolumn{2}{|c|}{ Total Sugar $(\%)$} & \multicolumn{2}{|c|}{ Phenols (\%) } \\
\hline & \begin{tabular}{|l|}
$\begin{array}{l}\text { Control } \\
\text { ripe }\end{array}$ \\
\end{tabular} & $\begin{array}{l}\text { Full } \\
\text { ripe }\end{array}$ & $\begin{array}{c}\text { Control } \\
\text { ripe }\end{array}$ & $\begin{array}{l}\text { Full } \\
\text { ripe }\end{array}$ & $\begin{array}{c}\text { Control } \\
\text { ripe }\end{array}$ & $\begin{array}{l}\text { Full } \\
\text { ripe }\end{array}$ & $\begin{array}{c}\text { Control } \\
\text { ripe }\end{array}$ & $\begin{array}{l}\text { Full } \\
\text { ripe }\end{array}$ & $\begin{array}{l}\begin{array}{l}\text { Control } \\
\text { ripe }\end{array} \\
\end{array}$ & $\begin{array}{l}\text { Full } \\
\text { ripe }\end{array}$ & $\begin{array}{c}\text { Control } \\
\text { ripe }\end{array}$ & $\begin{array}{l}\text { Full } \\
\text { ripe }\end{array}$ & $\begin{array}{c}\text { Control } \\
\text { ripe }\end{array}$ & $\begin{array}{l}\text { Full } \\
\text { ripe }\end{array}$ & $\begin{array}{c}\text { Control } \\
\text { ripe }\end{array}$ & $\begin{array}{l}\text { Full } \\
\text { ripe }\end{array}$ \\
\hline $\mathrm{T}_{1-} \mathrm{Ca} \mathrm{Cl}_{2} 0.5 \%$ (Single spray) & 18.7 & 20.0 & 0.19 & 0.14 & 13.48 & 14.42 & 0.68 & 0.50 & 19.3 & 20.6 & 0.20 & 0.12 & 14.5 & 15.42 & 0.62 & 0.47 \\
\hline $\mathrm{T}_{2-} \mathrm{Ca} \mathrm{Cl}_{2} 0.5 \%$ (Double spray) & 17.7 & 20.4 & 0.23 & 0.16 & 12.72 & 14.68 & 0.82 & 0.50 & 18.7 & 21.2 & 0.23 & 0.14 & 14.1 & 15.68 & 0.71 & 0.45 \\
\hline $\mathrm{T}_{3-} \mathrm{Ca} \mathrm{Cl}_{2} 1 \%$ (Single spray) & 18.0 & 20.8 & 0.21 & 0.12 & 12.96 & 14.95 & 0.72 & 0.53 & 18.3 & 21.0 & 0.25 & 0.11 & 13.7 & 15.95 & 0.79 & 0.50 \\
\hline $\mathrm{T}_{4-} \mathrm{Ca} \mathrm{Cl}_{2} 1 \%$ (Double spray) & 17.9 & 21.0 & 0.23 & 0.12 & 12.86 & 15.18 & 0.79 & 0.55 & 18.1 & 22.0 & 0.30 & 0.11 & 13.6 & 16.18 & 0.92 & 0.52 \\
\hline $\mathrm{T}_{5-} \mathrm{Ca} \mathrm{NO}_{3} 0.5 \%$ (Single spray) & 18.6 & 20.0 & 0.22 & 0.15 & 13.39 & 14.50 & 0.77 & 0.50 & 19.0 & 21.0 & 0.23 & 0.13 & 14.3 & 15.50 & 0.70 & 0.47 \\
\hline $\mathrm{T}_{6-} \mathrm{Ca} \mathrm{NO}_{3} 0.5 \%$ (Double spray) & 16.8 & 20.6 & 0.30 & 0.14 & 12.10 & 14.80 & 0.95 & 0.52 & 18.7 & 21.6 & 0.25 & 0.11 & 14.0 & 14.80 & 0.76 & 0.52 \\
\hline $\mathrm{T}_{7-} \mathrm{Ca} \mathrm{NO} \mathrm{NO}_{3} 1 \%$ (Single spray) & 16.8 & 20.8 & 0.31 & 0.12 & 12.10 & 14.97 & 1.03 & 0.55 & 18.1 & 21.8 & 0.30 & 0.12 & 13.6 & 15.97 & 0.93 & 0.53 \\
\hline $\mathrm{T}_{8}-\mathrm{Ca} \mathrm{NO}_{3} 1 \%$ (Double spray) & 16.8 & 21.2 & 0.37 & 0.12 & 12.07 & 15.26 & 1.05 & 0.54 & 17.2 & 22.2 & 0.31 & 0.11 & 12.9 & 16.26 & 0.97 & 0.52 \\
\hline$T_{9-}$ Control & 19.9 & 19.9 & 0.14 & 0.14 & 14.39 & 14.39 & 0.50 & 0.50 & 20.0 & 20.0 & 0.14 & 0.14 & 15.0 & 14.39 & 0.44 & 0.44 \\
\hline $\mathrm{SEm} \pm$ & 0.11 & 0.11 & 0.01 & $\mathbf{0 . 0 3}$ & 0.09 & 0.07 & $\mathbf{0 . 0 3 5}$ & 0.06 & 0.08 & 0.11 & 0.005 & $\mathbf{0 . 0 3}$ & 0.06 & 0.16 & 0.01 & $\mathbf{0 . 0 3}$ \\
\hline $\mathrm{CD}$ at $5 \%$ & 0.34 & 0.32 & $\mathbf{0 . 0 3}$ & NS & 0.26 & 0.21 & 0.105 & NS & 0.23 & 0.32 & 0.014 & NS & 0.17 & 0.46 & 0.04 & NS \\
\hline
\end{tabular}


Among the calcium compounds $\mathrm{CaNO}_{3}$ was slight better over $\mathrm{CaCl}_{2}$ applied at 1 per cent twice for enhancing mango shelf life and fruit quality in cv. Dashehari and Amrapali due to higher $\mathrm{CaCl}_{2}$ application caused marginal and lamellar scorching of leaves (Singh et al., 1993). These results are in accordance with finding of Romero-Gomezcana, et al. (2006) with mango cv. 'Haden', Singh, et al. (1998) with mango cv. Amrapali and Convey et al., 2003 with apple.

Thus, two pre harvests spraying of calcium nitrate $\left(\mathrm{Ca} \mathrm{NO} \mathrm{NO}_{3}\right) @ 1$ per cent prior to one month of harvesting i.e. late May and early June were enhanced the shelf life and fruit quality of mango fruits.

\section{Acknowledgements}

We thank to CPI, NAIP, Ag. Economics and Management, Udaipur along with PC cell AICRP on STF, CSH, Lucknow and Agricultural Research Station incharge and staff members for kind cooperation.

\section{References}

Anonymous 2015. National Horticulture board. Area and Production Estimates for Horticulture Crops for 2014.

A.O.A.C., 1995. Official Methods of Analysis Association of Official Analytical Chemist, Washington D.C. 16: 37.

Convey, W.S., C.E. Sams and K.D. Hickey, 2003. Pre and post harvest calcium treatments of apple fruit and its effect on quality. Acta Hort., 594: 325-321.

Dubois, M., K.Gilles, J.K. Hamilton, P.A. Robbers and F. Smith, 1951. A colorimetric method for determination of sugar. Nature, $16: 167$.

Eimer, P.A.G., T.M. Spiers and P.N. Wood. 2006. Effect of pre harvest foliar calcium spray on fruit calcium level and brown rot of peaches. Crop protection, 26:11-18.

Fry, S.C. 2004. Primary cell wall metabolism: tracking the carriers of wall polymers in living cells. New Phytol., 161:641675.

Kwon Hea, Ryoung, park kuen Woo, Kang Homin, H.R. Kwon, K.W., Park and H.M. Kang, 1999. Effect of post harvest heat treatment and calcium application on the storability of cucumber (Cucumis sativus L.). J.Korean Soc. Hort. Sci., 40:183-187.

Lanaouskas J. and N. Kvikliene, 2006. Effect of calcium foliar application on some fruit quality characteristics of Sinap orlovskji apple. Agron. Res., 4:31-36.

Panse, V.G. and P.V. Sukhatme, 1985. Statistical Methods for Agricultural Workers. ICAR, New Delhi pp. 145156.

Romero-Gomezcana, N.R. Saucedo-Veloz, C. Sanchez-Garcia, P. RodriguezAlcazar, J. Gonzalez-Hernandez, V. M. Rodriguez-Mendoza, M. N. BaezSanudo, R. Terra, 2006. Foliar application of calcium: physiology and fruit quality of 'Haden' mango. Sociedad Mexicana de la Ciencia del Suelo A.C., 24(4):521-527.

Rangana, S. 1979. Hand book of analysis and quality control for fruit and vegetables products. Tata Mc-Grow Hill Publishing Co. Ltd., New Delhi.

Sams, C.E. and W.S. Conway, 1984. Effect of calcium infiltration on ethylene production, respiration rate, soluble polyuronide content and quality of 'Golden Delicious' apple fruit. J. Am. Soc. Hort. Sci., 109 : 53-57.

Singh, S., V.Brahmachari and K.K. Jha, 1998. Effect of calcium and polythene wrapping on storage life of mango. Indian J. Horti., 55 (3):218-222.

Sharma, R.M., R. Yamdagni, H. Gaur and R.K. Shukla, 1996. Role of calcium in horticulture. Haryana J. Hort. Sci., 
25:205-212.

Singh, R. P.; D. K. Tandon and S. K. Kalra, 1993. Changes in postharvest quality of mangoes affected by pre harvest application of calcium salts. Scientia Horticulturae, 54 (3):211-219.

Singh, V., D.K. Sarolia, R.A. Kaushik, G.S. Ameta, 2012. Spray of calcium compounds for improving shelf life of harvested mango fruits. Global Conference on Horticulture for Food, Nutrition and Livelihood options, 2831May 2012) Bhuveneshwar (Odisha):274.

Stow, J. 1993. Effect of calcium ions on apple fruit softening during ripening. Post harvest Biol. and Tech., 3: 1-9.

Suhardi, Y. 1992. Ripening retardation of Arumanis mango. ASEAN Food J., 7: 207-208.

Tandon, D.K. and S.K. Kalra, 1997. Ripening of early harvested Dashehari mangoes with ethrel along with polyethylene packaging. Indian Food Packer, 51: 11-14.

Tirmazi, S.I.H. and R.B.H. Wills, 1981. Retardation of ripening of mangoes by post harvest application of calcium. Trop. Agric., (Trinidad) 58: 137-141.

\section{How to cite this article:}

Virendra Singh, G. Pandey, D.K. Sarolia, R.A. Kaushik and Gora, J.S. 2017. Influence of Pre Harvest Application of Calcium on Shelf Life and Fruit Quality of Mango (Mangifera indica L.) Cultivars. Int.J.Curr.Microbiol.App.Sci. 6(4): 1366-1372. doi: https://doi.org/10.20546/ijcmas.2017.604.167 